\title{
Stalagmites: from Science Application to Museumization
}

\author{
Andrea Columbu $^{1}$ (D) Laura Calabrò $^{1} \cdot$ Veronica Chiarini $^{1} \cdot$ Jo De Waele ${ }^{1}$
}

Received: 26 October 2020 / Accepted: 18 May 2021 / Published online: 30 May 2021

(c) The Author(s) 2021

\begin{abstract}
The concept of geoheritage is related to places of geological interest, generally of aesthetic, cultural, socio-economic and/ or scientific value. Many geosites are of karstic nature, because of their intrinsic beauty, their singularity and high geodiversity. Caves are among the most visited and economically exploited geological landforms. They constitute geosites as a whole, with their scenic landscapes, hydrogeological importance and the presence of bewildering natural rock and mineral formations including stalactites, stalagmites, flowstones and many other bizarre speleothem shapes. In some cases, a single speleothem, and the palaeoclimate record it contains, can be on its own of extraordinary importance to science. Once studied, these samples are often stored in research institution collections, rarely accessible to the wide public. In this paper, we report on the museumization of a stalagmite that has delivered a unique and exceptionally long glacial climate record from southern Italy, shedding light on the causes that led to the Neanderthal contraction and Modern Human expansion in this mild Mediterranean climate between 45 and 42 thousands years ago. The proposed museumization aims to demonstrate the potential of speleothems, after scientific application, in terms of educational and tourist resources. This approach allows to highlight the scientific importance of karst and cave geosites to the wide public, promoting their conservation and the valorisation of the studied cave-material.
\end{abstract}

Keywords Speleothem $\cdot$ Palaeoclimate record $\cdot$ Karst $\cdot$ Museum $\cdot$ Neanderthal $\cdot$ Geosites $\cdot$ Geological heritage $\cdot$ Science communication

\section{Introduction}

In the past, nature conservation was usually focused on its biological components, while geological features were mainly considered a platform on which biological systems are situated (Sharples 1995). However, in the late nineties, awareness towards the importance to protect the geological heritage has considerably increased (Wimbledon 1996). This led to the identification and protection of geological

Andrea Columbu

andrea.columbu2@unibo.it

Laura Calabrò

laura.calabro@studio.unibo.it

Veronica Chiarini

veronica.chiarini3@gmail.com

Jo De Waele

jo.dewaele@unibo.it

1 Department of Biological, Geological and Environmental Sciences, University of Bologna, Via Zamboni 67, 40126 Bologna, Italy landforms identified as 'geosites', which are characterized by aesthetic, cultural, socio-economic and/or scientific value (Panizza 2001; Brilha 2016). The birth of the European Association for the Conservation of Geological Heritage-ProGEO dates back to this period; additionally, the research project 'GEOSITES' was launched by the International Union of Geological Sciences (IUGS) (Wimbledon 1996). This project, still ongoing, aims to create an international digital inventory of relevant geological sites to support both scientific research and political decision-making for the conservation of the geological heritage. Accordingly, aspects related to geoheritage, geodiversity, geosites and geomorphosites are now widely discussed among researchers (Panizza 2001; Reynard and Panizza 2005; Pereira and Pereira 2010; Coratza and De Waele 2012; Brilha 2016). In Italy, the project 'National Inventory Geosites' started in 2002 and was promoted by the Institute for the Environmental Protection (ISPRA). At a regional level, further databases exist where geosites are subdivided according to their relevance (i.e. regional or national). Importantly, karst areas and caves are often identified as geosites, and 
many karst sites are listed as UNESCO World Heritage Sites (Williams 2008). Indeed, these landforms hold a great value in terms of both nature conservation, tourism promotion and scientific research (van Beynen 2011; Delle Rose et al. 2014; Santangelo et al. 2015; Ruban 2018; Sardella et al. 2019; Nyssen et al. 2020).

Cave science developed exponentially over the last years. Several disciplines exploit caves for scientific purposes, among which the most important are archaeology, geology, geography and biology. The results have been brilliant, with several breakthrough discoveries (Benazzi et al. 2015; Hoffmann et al. 2018; Dumitru et al. 2019; Trontelj et al. 2019; Bajo et al. 2020). Furthermore, it is likely that in the near future, more and more scientists will frequent caves thanks to the technological advancements in exploration and analytical analyses on cave-derived material. For example, a multi-kilometre long karst system has been recently discovered in the Tepui mountains (Venezuela) (Sauro et al. 2018, 2019) that develops within quartzite, a bedrock in which the presence of extensive dissolution caves was considered unlikely until a few years ago (Wray and Sauro 2017). On the other hand, scientific and technological advancement in DNA-based analyses only recently have allowed application on cave chemical precipitates (Stahlschmidt et al. 2019). Although just the presence of humans could compromise their delicate microenvironment, sometimes untouched for even millions of years (Leuko et al. 2017), most of the cavebased studies are non-invasive and/or semi-invasive with respect to the sampled material. Indeed, caves are often equipped with instruments that are removed once the project finishes, as for example in the case of environmental monitoring (Baker et al. 2019) and studies on sound propagation (Revilla-Martín et al. 2020). In other circumstances, only negligible amounts of liquid and/or rocky material are sampled, as for mineralogical and hydrogeological studies (Mecchia et al. 2019). Considering archaeological excavations, in most cases, trenches are usually around the cave entrance (Romandini et al. 2020), while the cave interior often remains untouched. All in all, these (and other) scientific activities accomplished in caves have no significant consequences for the underground landscape.

In the last two decades, cave-based palaeoclimate studies have greatly developed too (Fairchild and Baker 2012). This is because speleothems can be radiometrically dated with extremely high precision by using the uranium-series method. At the same time, speleothems provide a plethora of geochemical (oxygen and carbon stable isotopes, trace elements, etc.) and physical (growth rate, fabric, etc.) characteristics that, rigidly constrained in time-series, can be applied as palaeoclimate proxies (McDermott 2004). However, contrarily to other cave-related disciplines, this science requires the removal of a remarkable amount of material, often involving the most iconic elements composing the cave landscape: stalagmites. Although several approaches have been proposed to try to limit the irreversible damage to the cave landscape (Frappier 2008; Spötl and Mattey 2012; Scroxton et al. 2016; Weij et al. 2018), there is almost no way back once stalagmites have been sampled, considering that chemical-physical analyses involve the partial destruction of the stalagmite itself, but not all sampled stalagmites are actually used for producing palaeoclimate data. After slicing and/or preliminary analyses, most of the stalagmites are judged not suitable for more detailed investigations and therefore discarded. In any case, the fate of most sampled stalagmites is to end up in university collections, seldom visited by students or researchers only (de Lima and de Souza Carvalho 2020a). Most of the time, they rest in dusty shelves for an undetermined amount of time.

This paper presents a way to exploit stalagmites, after scientific applications, from an educational point of view. It aims to boost the awareness towards the scientific importance of karst and cave geosites, promoting their conservation and the valorisation of the cave-material studied. We here report the plan of museumization we adopted for a stalagmite sampled in Pozzo Cucù Cave (Southern Italy, Fig. 1); the geochemical study of this stalagmite was crucial for recent advancements in the field of palaeoclimatology and anthropology (Columbu et al. 2020). The museumization of stalagmites is frequent in geological and natural museums (Currens 1981), although they are seldom displayed for scientific and didactic purposes. For example, the geological museum of the Courel Mountains UNESCO Global Geopark in Spain shows stalagmites studied by Railsback et al. (2017); similarly, the museum of the Castañar de Ibor cave displays the specimens studied in Alonso-Zarza et al. (2012). Other examples are the Jackson School of Geosciences at the University of Texas in Austin (USA), the Carnegie Museum of Natural History in Pittsburgh (USA), The National Museum of Natural History in Manila (Philippines), the National History Museum in London (the Red Zone), just to mention a few. Some exhibitions have all but a scientific interest, using stalagmites and speleothems as scenic natural sculptures, such as in the Gysean Global Village Folk Museum in Daegu (South Korea) or the Bristol City Museum (UK). Some museums also have reconstructions of entire cave systems, such as in Cincinnati (USA). However, in-detail studies on museumization of speleothems for didactic purposes are still scarce. Accordingly, the aim of this work is to demonstrate that the utility of stalagmites, and all speleothems by extension, continues after scientific application, this time in terms of educational and tourist resources. Aiming to compensate the irreversible damage caused to the cave landscape, and maximize the employment of stalagmites after their removal from their natural environment, this paper suggests to the entire 


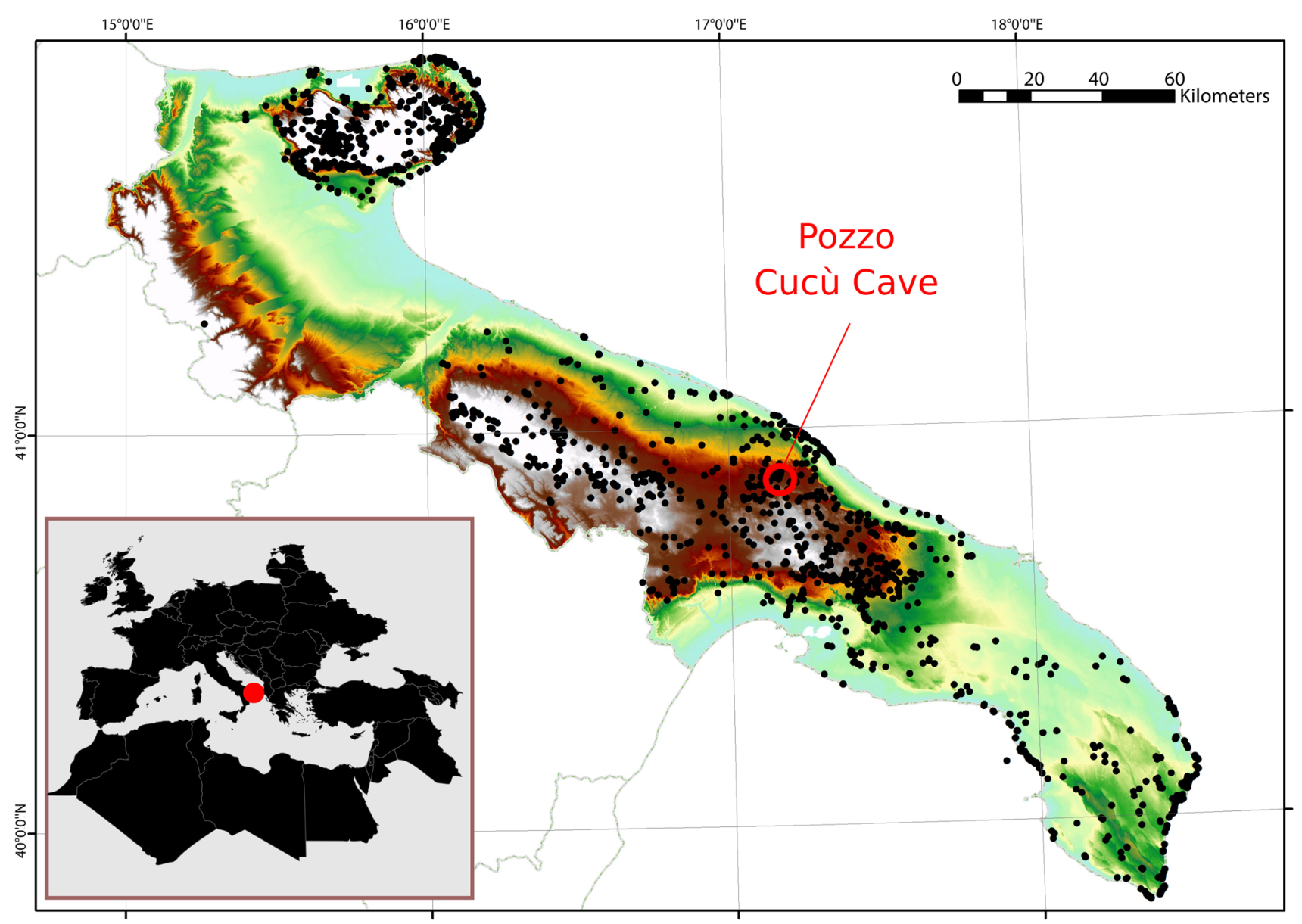

Fig. 1 Location of Pozzo Cucù Cave (red circle) in Apulia region, Southern Italy. Black dots indicate the $>3000$ caves mapped in this region (from the Apulian governmental cave registry available on-line)

speleothem community an easy-to-do method to valorize this special geoheritage.

\section{Caves: a Conflict Between Science and Conservation}

Caves are delicate environments under different perspectives. From a biological point of view, there are species that occasionally frequent underground habitats (i.e. trogloxenes and trogophiles), but also organisms (i.e. troglobites) that undergo their whole life cycle in caves. These species have adapted to this dark and oligotrophic environment for thousands and possibly millions years (Culver and Pipan 2019). Their subsistence relies on a subtle equilibrium of their ecosystem, which is sustained by the stable conditions of caves throughout the year (in terms of temperature, moisture, availability of nutrients, etc.). The consequences of the human frequentation cause disturbance to cave habitats, leading to an ecological stress for the species that live there. Other ecological niches, although still poorly known, are those constituted by microorganisms (Barton and Northup 2007). Their aggregation into colonies can create morphologies visible at naked eye, as for example vermiculations (Addesso et al. 2019). However, most of the time these microorganisms are invisible, and their identification is only possible by DNA studies (Sauro et al. 2018). Although some thrive on organic substances brought into the cave by flowing water, gravity, wind or animals, some are true autotrophs, and geochemical parameters such as water $\mathrm{pH}$ and/ or mineralization are essential for their subsistence. While human presence can indeed influence these habitats (Leuko et al. 2017), it is important to maintain these niches pristine because, often, microorganisms have evolved in chemicalphysical-ecological conditions totally different with respect to the Earth surface, thus can be useful indicators of life conditions of the early Earth and/or other planetary subsurfaces (Boston et al. 2001).

Under a geological perspective, caves contain unique mineralogical formations, often peculiar from one cave to another. The uniqueness lies both in the shape and composition, and can consist in giant crystals (Forti and Sanna 
2010), rare minerals (Galli et al. 2013) and unusual speleothems (Tisato et al. 2015; Bontognali et al. 2016). In this case, the damage can be the modification of chemical/physical parameters inducing the formation of a certain mineralogical species and/or their breakage. For example, cave formations are often white in colour; careless cavers and scientists can irremediably disrupt their original appearance by only touching with dirty hands and/or walking over them with muddy boots.

Scientists willing to perform speleothem sampling have to take into account the above-reported risks when exploring caves. Additionally, the intended practice is per se invasive, considering the (often conspicuous) removal of material from its original environment. Some research groups follow an ethos (Lourenço and Wilson 2013) during sampling campaigns, and only already broken speleothems are removed (Scroxton et al. 2016; Weij et al. 2018); this approach can be applied both to stalagmites (Chiarini et al. 2017; Woodhead et al. 2019) and flowstones (Columbu et al. 2017a). For several reasons, not all research groups follow these approaches. The will to produce long and continuous palaeoclimate records leads to discard this more conservative approach (Scroxton et al. 2016), although our sample demonstrated a continuous 80 thousand years long palaeoclimate record from a stalagmite found already broken in the cave (Columbu et al. 2020). Also, it can be difficult and time-consuming to only target the broken ones. Sampling campaigns are often accomplished in remote areas, where there is the need to collect as much as possible promising samples in the shortest time. Another practice is to core large flowstones (Columbu et al. 2019b; Regattieri et al. 2019). Eventually, the hole produced by the coring can be easily plugged with cave materials (e.g. sediments), hence reducing the visual impact of sampling. Flowstone coring is rarely accomplished because the genesis of these speleothems, contrary to stalagmites, can produce peculiar geochemical characteristics that impede a correct geochemical interpretation for palaeoclimate purposes. This is a pity, considering that flowstones can potentially produce very long records (Pozzi et al. 2019). The shortcut is to select a still-standing stalagmite that is considered promising for geochemical analyses (usually candle-shaped stalagmites) and remove it at its base. However, because of the unknowns regarding the speleothem age and the effective feasibility of analyses, this cutting operation is often accomplished on several stalagmites and in multiple caves. Consequently, the original subterranean heritage is compromised irreversibly.

Stalagmites could theoretically be reinstalled in caves if, after their sampling, they are not considered adequate for palaeoclimate studies. However, this can only be accomplished if speleothems are not sliced and their internal structure is preliminarily investigated by, for example, X-ray tomography (Walczak et al. 2015). As a matter of fact, this time - and money - consuming approach is basically never applied. Preliminary observations could also be carried out by coring, instead of slicing, the selected stalagmite. However, this risky practice (the stalagmite could break into pieces during coring) can only be applied to mediumor large-size stalagmites. In any case, the reinstallation is unlikely in the case of expeditions to remote areas (because of time and resources).

Frappier (2008) proposed a screening system to select the most suitable sample(s) avoiding massive sampling; this requires sequential operations, also involving cave monitoring, that are not always affordable by all research groups. It has also been demonstrated that the extraction of mini-cores from in-situ stalagmites can successfully provide useful information on palaeoclimate-driven speleothem growth history (Scroxton et al. 2016). Coring is targeted at the bottom and top of stalagmites; thus, removal is not necessary. However, this minimally invasive approach is inapplicable if the intent is the creation of proxy-based (i.e. oxygen and carbon stable isotopes) palaeoclimate time-series from stalagmites.

It is evident that speleothem-based palaeoclimate science requires the modification of cave landscapes. Notwithstanding, contrarily to other rocks, stalagmites are usually characterized by an attractive visual aspect, because of the shape, colours and internal fabric. Indeed, after slicing and polishing, speleothems show eye-catching features, the reason why they are often exposed at natural history museums (Currens 1981). However, the general public is often unaware of the scientific potential of these carbonate deposits. Indeed, the museumization of stalagmites after scientific application could have the twofold aim of valorising a cave component removed from its original collocation while entertaining and educating people on topics related to palaeoclimate and the vulnerable and highly valuable cave environment.

\section{The PC Stalagmite and Its Scientific Importance}

Pozzo Cucù Cave is located in Apulia Region (Southern Italy, Figs. 1 and 2), in the province of Bari and in the municipality of Castellana Grotte. The latter is a well-known karst area (grotte means 'caves' in Italian), and the Castellana Show Cave is one of the most visited in Italy, with more than 300,000 tickets per year (Parise 2011). An important portion of the local economy relies on this cave, because of tickets profit and employment, as well as the touristic flux attracted by the underground landscape. More or less in the same area, $\sim 50 \mathrm{~km}$ west nearby the town of Altamura, there is Lamalunga Cave, which is worldwide famous for hosting the remnants of the so called 'Altamura Man', a pristine skeleton of an ancient Neanderthal man covered by calcite crusts (Vanghi et al. 2017). Indeed, Apulia is a hot spot for 


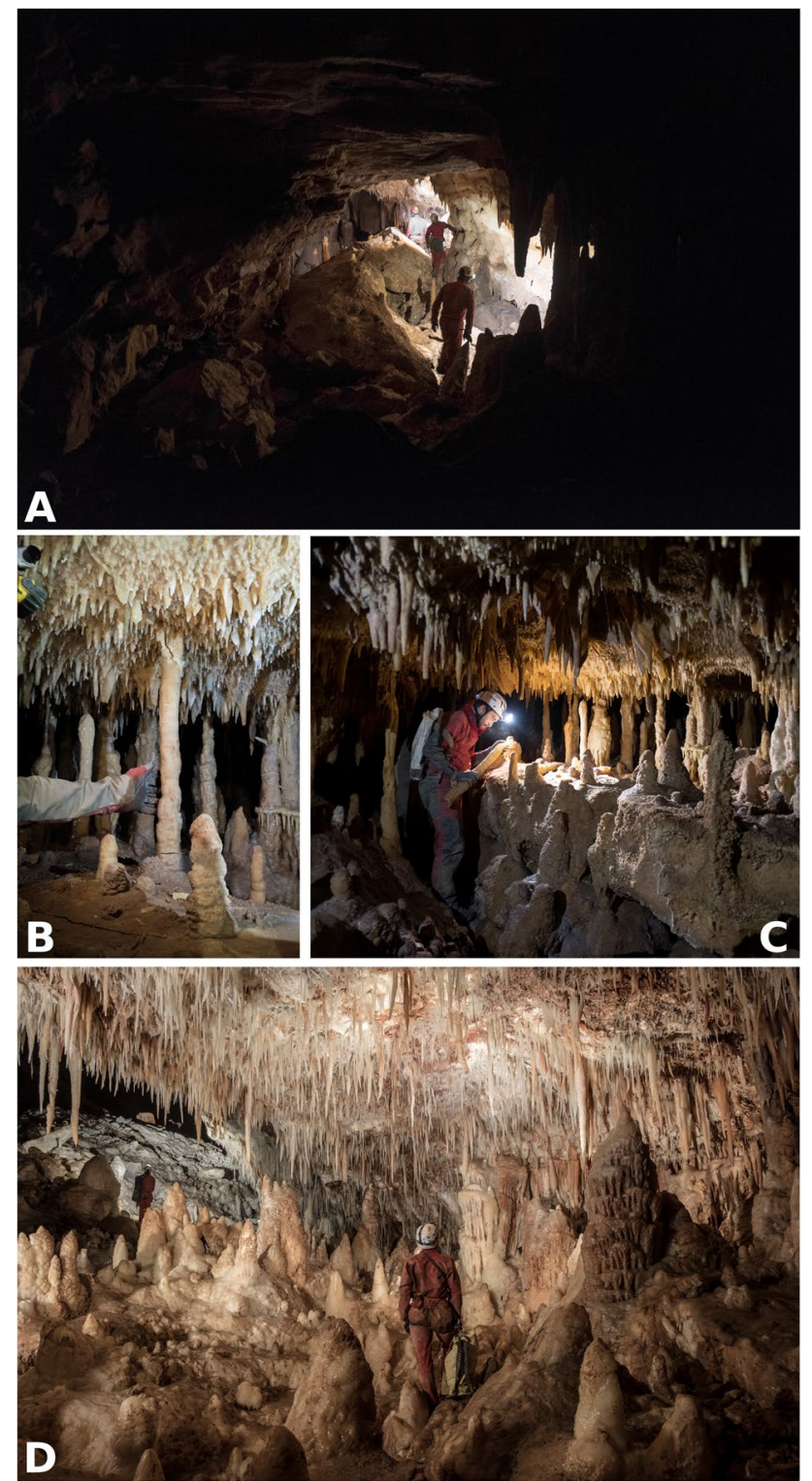

Fig. 2 Caves in Apulia. Pozzo Cucù Cave explored by scientists and local speleologists (A). A Broken stalagmite (B, see the fractures at the base and top) is checked by a scientist (C) in Pozzo Cucú Cave. Grave Santa Lucia Cave (D) and its multitude of white, very delicate, carbonate formations. All photos taken by O. Lacarbonara

cave-based anthropological studies because of the multiple findings. For example, the fossils of the oldest European Sapiens have been found in this region (Benazzi et al. 2015). Importantly, this was one of the few areas in continental Europe where Sapiens and Neanderthals shared the same territory, from $\sim 45$ to $\sim 42$ thousand years ago (hereafter $\mathrm{ka}$ ), before the extinction of the latter (Benazzi et al. 2011; Higham et al. 2014).

Pozzo Cucù Cave is included in the Geosite Inventory of the Apulia Region with the code 'CGP0357'. Located around $10 \mathrm{~km}$ from the Adriatic coastline, it is carved in the Cretaceous limestone plateau belonging to the Calcare di Altamura Formation (Figs. 1 and 2). The modern entrance, a narrow $\sim 8 \mathrm{~m}$ deep pit at $\sim 270 \mathrm{~m}$ a.s.l., leads to a subhorizontal environment that stretches for $\sim 300 \mathrm{~m}$. A gate blocks the entrance, and access is allowed for scientific purpose upon permission by local authorities; exploration is permitted to expert speleologists only. This is a valid conservation method, considering that the cave is decorated by pristine carbonate formations, most of which are delicate and could be easily broken by inexperienced visitors (Fig. 2). PC stalagmite (Fig. 3) was found detached - but nearby - its original position. It has grown over loose sediments, in part constituted by fossils of large mammals. It is the unstable nature of these sediments that likely caused the fall of the stalagmite, perhaps after earthquakes and/or low discharge flooding. We tend to exclude intense episodes of flooding because (1) the stalagmite and fossils would have been scattered around the cave and (2) other evidences of flooding would have been found in the cave. PC appears as a $46 \mathrm{~cm}$ long candle-shaped stalagmite, composed of yellowish to brownish calcite (Fig. 3). After slicing along the growth axis, the two halves were polished to obtain a better visualization of the internal macrofabrics. The stalagmite exhibits a well-preserved lamination from the bottom to $3 / 4$ of its height, while the remaining portion (i.e. the first $\sim 10 \mathrm{~cm}$ from the top) is composed of translucent calcite. After preliminary U-Th dating $(n=3)$, which attested its possible formation during the last glacial period, dating with very high spatial resolution was carried out along the growth axis, obtaining a total of 27 ages. Dating was executed at the Melbourne University (Australia), School of Earth Sciences, following tested protocols (Columbu et al. 2017b, 2019a). Additionally, a stalagmite half was further halved along the growth axis in order to facilitate the operations of high resolution sampling for oxygen $\left(\delta^{18} \mathrm{O}\right)$ and carbon $\left(\delta^{13} \mathrm{C}\right)$ stable isotopes. The latter were accomplished at the Innsbruck University (Austria), Institute of Geology, with a spacing of $0.1-0.2 \mathrm{~mm}$ for a total of 2659 analyses that followed tested protocols (Moseley et al. 2020). This set of analyses allowed to create the longest and continuous European speleothem-based palaeoclimate record for the last glacial period (Comas-Bru et al. 2020). In fact, PC stalagmite continuously grew from $106.0^{+2.8 /}{ }_{-2.7}$ to $26.6^{+0.8 /}{ }_{-0.9} \mathrm{ka}$ (Columbu et al. 2020) (Fig. 3).

It resulted as a rare, possibly unique, specimen in the European and Mediterranean context. In fact, in this macro region, the prolonged deposition of cave calcite in colderthan-now climate regimes is impeded because of the drier and colder conditions. PC record is an ideal candidate to become a 'reference record' to which new Mediterranean, European and even global palaeoclimate reconstruction will be compared to, considering that the $\delta^{18} \mathrm{O}-\delta^{13} \mathrm{C}$ variations demonstrated a strong global signal (i.e. the climate was 


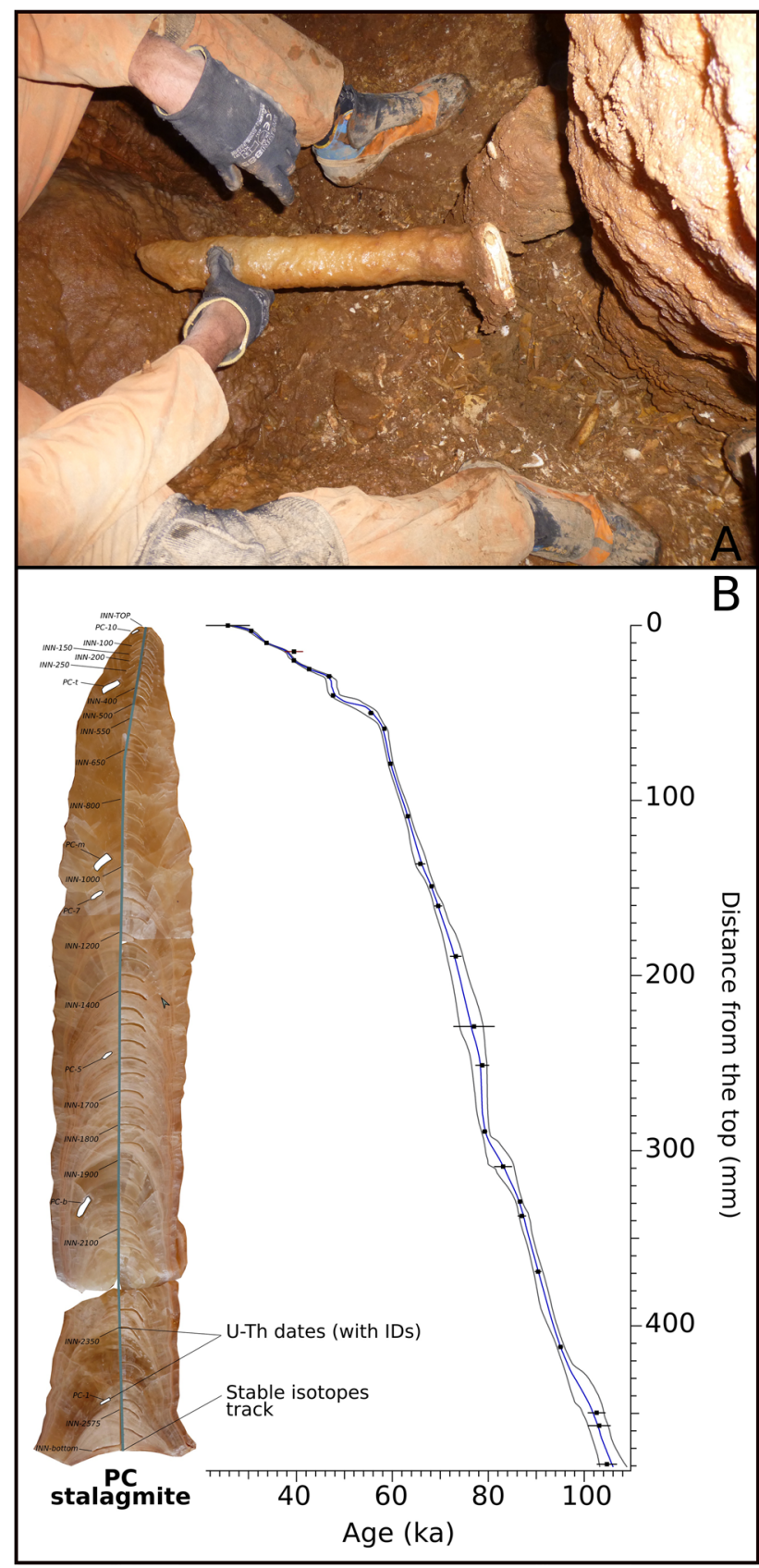

Fig. 3 The PC stalagmite. A-The sample as it was found in the cave. Note the remains of big mammals scattered on the ground, a loose surface where possibly the stalagmite originally grew. B-The PC stalagmite slice used for dating (black lines and IDs) and stable isotopes analyses (blue vertical line). On the right there is the age depth model, showing that the stalagmite continuously grew from 106 to $\sim 27 \mathrm{ka}$ (dots and bars are respectively the obtained U-Th ages and the uncertainties, while the envelope is the calculated age model). After Columbu et al. (2020)

controlled by climate variations occurring in Greenland and the Atlantic Ocean), but modulated by a regional signal (i.e. climate influenced by variations occurring within the Mediterranean basin) (Fig. 4). Most importantly, the interpretation of $\mathrm{PC} \delta^{18} \mathrm{O}-\delta^{13} \mathrm{C}$ time-series sheds light on the climate status during the following: (1) the late settlement of Neanderthal in Apulia ( 106 to $\sim 2 \mathrm{ka}$ ); (2) the arrival of Sapiens in Apulia ( 45 ka); (3) the 3000 years long cohabitation of the two human species; (4) the Neanderthal extinction ( $42 \mathrm{ka})$. The Sapiens-Neanderthal turnover is the most important cultural transition in Human history, yet there is no leading theory explaining this interchange. Climate variations, particularly the occurrence of frequent very harsh periods during the last glacial, have often been invoked as primary triggers of the Neanderthal demise in other localities (Finlayson and Carrion 2007; Wolf et al. 2018; Staubwasser et al. 2018; Melchionna et al. 2018). However, the PC record gave another view to this topic, attesting that during the Sapiens-Neanderthal turnover, climate in Apulia was never affected by dramatic cold and dry periods and relative environmental modifications that could have caused the extinction of Neanderthal in this region. Accordingly, Apulia has been defined as a 'climate niche' in that period. Because of PC record, it is now clear that in Apulia-like areas, i.e. mid-latitude regions where global climatic variations during the last glacial were attenuated by latitudinal, orographic and/or geographical factors, climate cannot be considered as the primary factor in Neanderthal demise (Columbu et al. 2020) and the consequent territorial supremacy of modern humans. The PC record indirectly reinforces the theories that see the advanced hunting technology of Sapiens groups compared to that of Neanderthals since their migration to Europe as a possible explanation for their turnover (Sano et al. 2019; Marciani et al. 2020) (Fig. 4).

\section{The Museumization Approach}

We here propose a plan for the museumization of the PC stalagmite, which has been agreed with the Castellana Cave society. The latter greatly contributed for the PC scientific venture, both from a financial and logistic aspect, and it is now participating in this new phase. Indeed, the institution selected for the display, to which the sample will be donated, is the Franco Anelli Speleological Museum. The museum is in Castellana Grotte, and belongs to the facilities of the Castellana Show Cave, which is supervised by the Castellana Society. All visitors accessing the show cave have free access to the Franco Anelli Museum; hence, the exposition is visited frequently throughout the year. Notwithstanding, the aim of selecting this institution is to bring back the stalagmite to its original region, considering the vicinity between Castellana and Pozzo Cucù. By extension, we suggest to all scientists willing to adopt the museumization approach to donate the speleothem to the closest available institution with respect to the cave where the speleothem has been collected. Before the donation, it is good practice 
Fig. 4 PC stable isotope timeseries $\left(\delta^{13} \mathrm{C}\right.$ on the top, $\delta^{18} \mathrm{O}$ on the bottom) compared to palaeoclimate reconstruction from Greenland ice core (NGRIP project members (2004), black curve in the centre). Bars on the bottom indicate Neanderthal and Modern Human (Sapiens) turnover. Grey vertical bars are the proposed correlation with NGRIP. The soil bioproductivity plateau $\left(\delta^{13} \mathrm{C}\right)$ and the moderate rainfall variation $\left(\delta^{18} \mathrm{O}\right)$ attest to stable environmental conditions during Neanderthal demise and Sapiens territorial predominance. After Columbu et al. (2020)

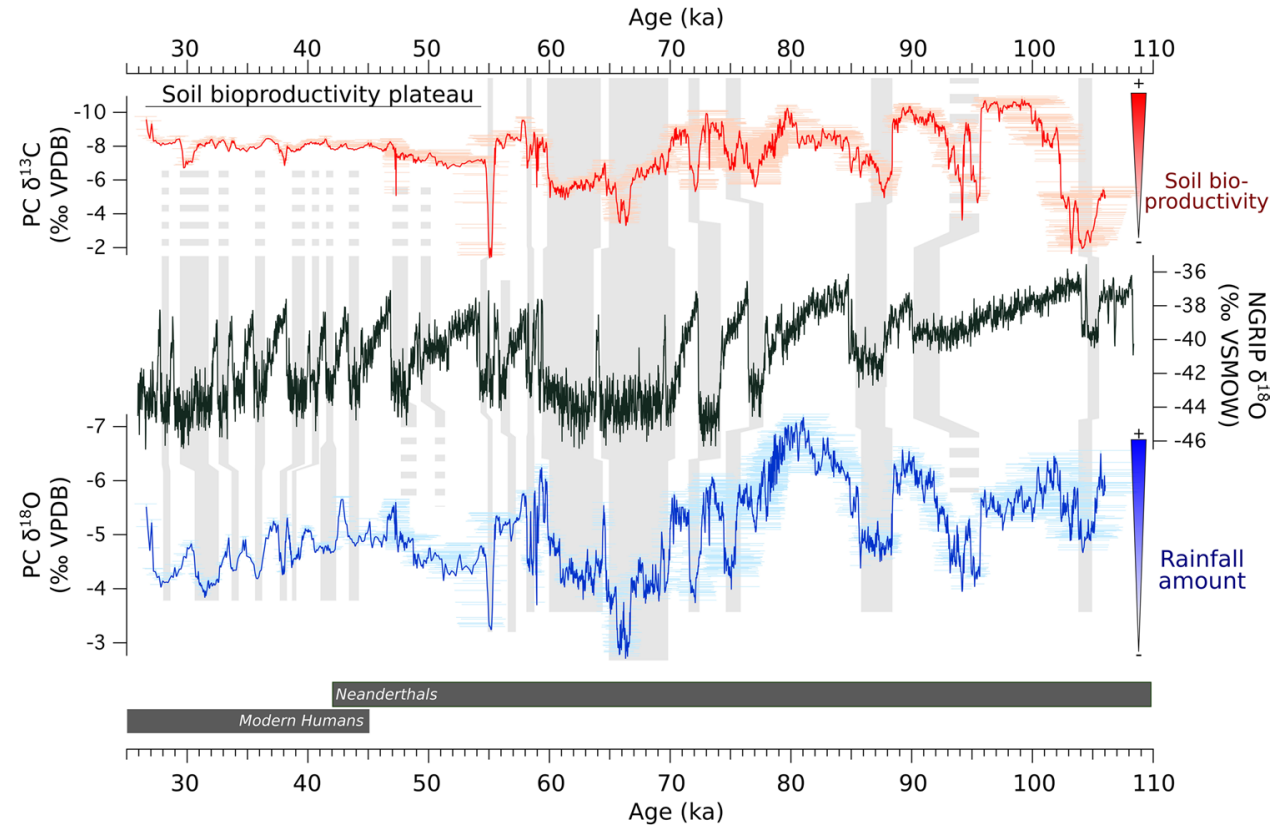

to make a full photographic documentation of the sample and compile a personal database with the most important characteristics of the specimen. This might turn useful to the next generation of scientists that could be willing to work on the same speleothem (Fairchild and Baker 2012).

The museumization requires the creation of two items: (1) the showcase where the stalagmite will be exhibited; (2) a didactic panel, which will be disclosed besides the case itself. The first, together with finding the appropriate collocation in the museum collection as well as planning the most suitable lighting, necessitates of the expertise and skills of the museum superintendent and his/her crew. Scientists should instead provide the contents of the second. We have thus created a didactic panel that will complete the exposition of the PC stalagmite (Fig. 5). This represents the principal 'supporting element' in scientific museums (Miglietta et al. 2011). Its layout is of key importance because the visitor should be able to identify the most important information and the level of details he is interested in. Besides the informative function, the panel often gives physical support to the object, becoming an integral part of the specimen itself (Bartoli et al. 1996). In this way, it captures the visitors' attention, which is attracted by its shape, colours and schematism. Indeed, the fruition by the visitor strictly depends on the interaction between text and graphic. These components should not be taken separately when planning the composition of a panel (Merzagora and Rodari 2007), in order to enhance the communicative power. The latter is favoured by taking into consideration the readability of the text and emphasis in the message delivered by the text, balance and coherence between elements and equilibrium between text and background. For example, text blocks are a useful expedient to fragment a long text, and visitors more easily remember the panel contents if text is proposed in short isolated paragraphs rather than a long continuous one (Appiano 1998). Additionally, it is important to avoid as much as possible scientific jargon, which could result hard to understand by the average public, while lexicon should be simple, non-redundant, captivating and supported by images. From a general perspective, the hierarchical order of the information must be straightforward in order to facilitate the comprehension and memorization, as well as to highlight a logical and easy-to-follow reading path.

The proposed panel (Fig. 5) is currently under evaluation by the Franco Anelli Museum superintendent. The chosen font is Verdana, because of its great readability even for smaller dimension text. The panel is bilingual (Italian and English), and the two languages are reported with two different text colours in order to better delineate the reading path. The Gulpease index (Lucisano and Piemontese 1988) was used to test the text readability, making contents fully comprehensible for the younger public (targeting middle school average students). The title and subtitle of the panel are characterized by vivid colour, in order to capture the public's attention immediately. The title itself is captivating, already stimulating the curiosity of the reader. The sub-title, instead, proposes a super condensed summary of the panel content, still procuring a sort of gap of information that the visitor can only fill by continuing the exploration of the panel. In the top corners, there is a brief explanation about the genesis of stalagmites and their potential for scientific applications. On the left, on the bottom part, there is instead a one-line message recalling the importance of the cave environment protection, which clearly establishes that removing 
cave deposits is allowed for scientific purpose only. Three short paragraphs compose the main reading path. They are numbered and connected by an arrow, extending from the left to the right of the panel. In this way, the visitor is invited to observe the panel in its whole. The path starts with a question about the importance of the stalagmite, which intrigues the reader and tempts to continue reading. The three blocks highlight the uniqueness of the sample (i.e. one of the few last glacial European stalagmites ever found) and the outcome of the scientific application (i.e. climate was not the main trigger of Neanderthal extinction in southern Italy). The central part is instead dedicated to the stalagmite itself. The intent of the big picture of the sample is to straightforwardly declare what the panel is about, and this can be noticed from distance (i.e. even at distance where text is non readable). Visitors are thus attracted by this expedient and conveyed toward the showcase. The two paragraphs beside the picture are a slightly detailed explanation on the geochemical analyses carried out on the stalagmite; the visitor might decide their reading according to the level of detail he/she is interested in. The panel also includes other two images: (1) on the left portion there is a picture taken in Pozzo Cucù Cave, which shows a scientist inspecting stalagmites for their sampling; (2) on the bottom right corner there is a proposed reconstruction of the Neanderthal and Sapiens appearance. This is the last component of the panel that the visitor should theoretically look at, as a take-home message that the exposed item (the stalagmite) is in some way telling a story about ancient populations. This is a powerful expedient for enhancing the possibilities that the visitors will remember the panel, and its main content, in the future.
However, aimed to visitors wishing more information, a QR code placed in this same portion of the panel connects to the scientific paper upon which the panel is based (Columbu et al. 2020).

The proposed museumization approach takes also into account an evaluation strategy (Economou 2004), which will help the museum superintendent to understand the audience appreciation and feelings toward the new exposition. A survey will assess how intriguing the content of the proposed panel is and how much the informative expedients enhance the visitors' memory. Experts in museum management will conceive the survey; the results will give the possibility to modify the panel if needed. In fact, the characteristics of the real or even potential public must be considered to clarify or adapt a cultural project (MacDonald 1992). The analysis of the survey information permits to increase the value of the cultural offer, making it more readable and attractive for a range of different types of visitors (Tobelen 2003). This will also allow to comprehend if this approach can be applied to other Italian and/or non-Italian museums, similar in contents and public. This is because the knowledge of the demography and social characteristics of the various kinds of public, as well as their motivations and expectations, are essential elements for the effectiveness of cultural management (Merzagora and Rodari 2007). Indeed, while in the past visitors were considered only figures to be counted, in the last few years, they have become attentive users (Kotler and Kotler 1999); curators must focus on them if the final aim is to achieve the main goals of modern museums, which are primarily to inform and educate (Posi et al. 2010).

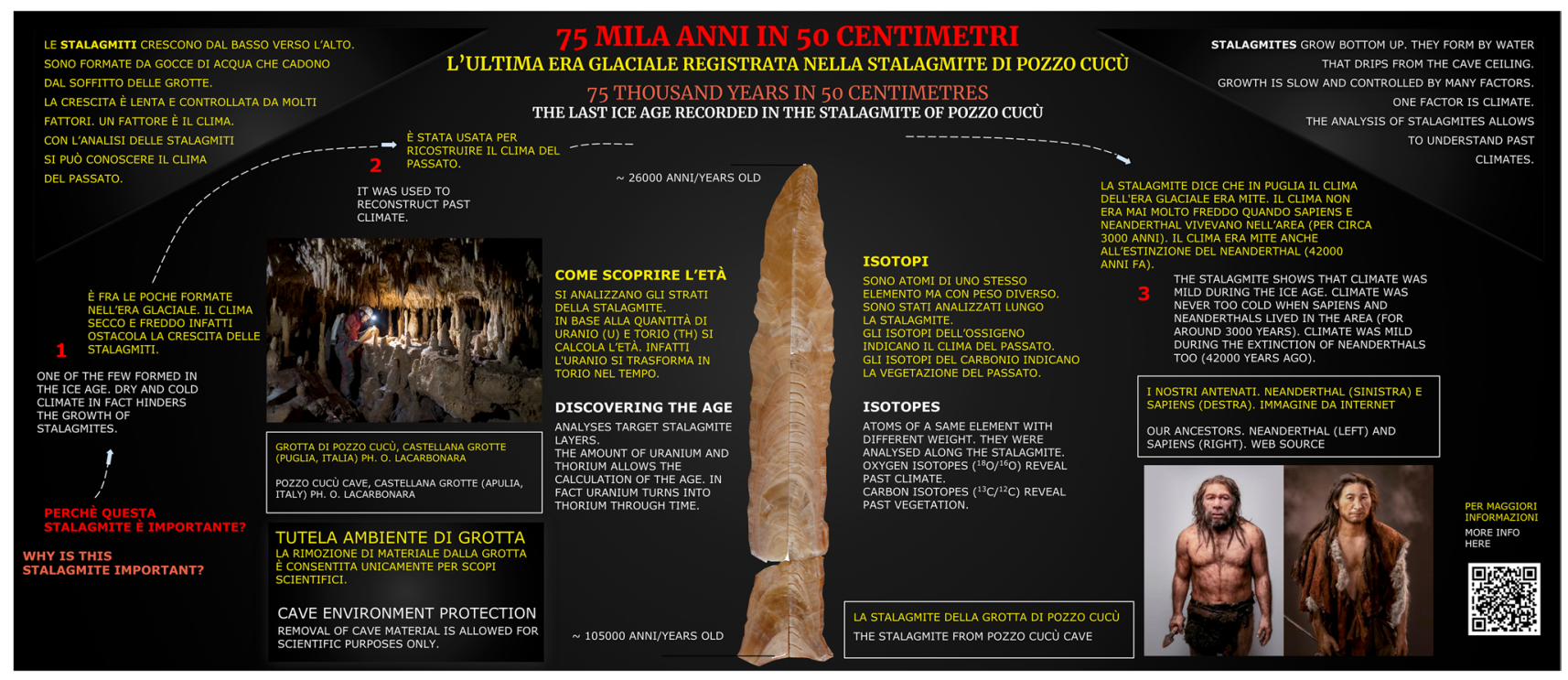

Fig. 5 The didactic panel created for the museumization of the PC stalagmite (see text for details). The final size will be decided according to the space available in the exposition room and its characteristics 
Last but not least, the final step of the museumization should be the advertising by authorities. Indeed, 'for an object to be considered as heritage, it is necessary to recognize value on it; if only one person recognizes it as such, it is not enough, since heritage is necessarily a collective concept' (de Lima and de Souza Carvalho 2020b). In our opinion, this process should be boosted by local authorities by a detailed and precise project of social and cultural enhancement of the represented heritage. This would gradually educate people on the importance of a single item as a record of a small slice of the ancient history and culture of a specific area.

\section{Conclusions}

Speleothems used for palaeoclimate research are usually disassembled by the multiple geochemical and petrographic analyses required for their full scientific exploitation. Generally, one half of the speleothem is spared, acting as a reference model for the exact location of samples, hiatuses and petrographic changes, as well as for future researches. This work proposed the museumization of a speleothem after scientific application. To this aim, we have selected the PC stalagmite that, in previous studies, has allowed the reconstruction of the changing climate conditions when Modern Humans gradually substituted Neanderthal groups in Apulia. This stalagmite, with its intriguing story, is a perfect sample to be displayed in a museum considering its scenic and scientific value. Indeed, the polished half of the speleothem is ideal for exhibition purposes, attracting the interest of visitors because of its aesthetic aspect. A panel has been designed to accompany this sample in a museum exhibition close to its original finding. The panel intends to highlight the scientific value of the sample, as well as to procure a didactic mean for visitors. This important stalagmite is a good example of how these samples, which are normally stored in collections of research institutions and are often lost or forgotten, can help in promoting the knowledge on palaeoclimate research in general, and of cave speleothems as palaeoclimate archives in the specific, becoming a useful tool for the karst geosites valorisation.

Acknowledgements The research on Pozzo Cucù has been possible thanks to the participation of the Gruppo Puglia Grotte (Castellana), the Grotte di Castellana Srl. (managers of the Castellana show cave), and the Federazione Speleologica Pugliese. Field work also involved cavers from different speleological groups, mainly Gruppo Speleologico Martinese, Gruppo Escursionistico Speleologico Ostunese GEOS and Centro Altamurano di Ricerche Speleologiche. Prof. Mario Parise (University of Bari) also helped during the sampling operations. The palaeoclimate research involved, besides Bologna University, the Universities of Melbourne (Australia) with Dr. John Hellstrom, Xi' an Jiaotong (China) with Prof. Hai Cheng, and Innsbruck (Austria) with Prof. Christoph Spötl. Anthropological interpretations were possible thanks to Prof. Stefano Benazzi (Bologna University). We are thus grateful to all the people that have contributed to this project. Finally, we are indebted to D. Ballesteros (Granada university, Spain) and an anonymous reviewer for the insightful comments.

Funding Open access funding provided by Alma Mater Studiorum Università di Bologna within the CRUI-CARE Agreement.

Open Access This article is licensed under a Creative Commons Attribution 4.0 International License, which permits use, sharing, adaptation, distribution and reproduction in any medium or format, as long as you give appropriate credit to the original author(s) and the source, provide a link to the Creative Commons licence, and indicate if changes were made. The images or other third party material in this article are included in the article's Creative Commons licence, unless indicated otherwise in a credit line to the material. If material is not included in the article's Creative Commons licence and your intended use is not permitted by statutory regulation or exceeds the permitted use, you will need to obtain permission directly from the copyright holder. To view a copy of this licence, visit http://creativecommons.org/licenses/by/4.0/.

\section{References}

Addesso R, Bellino A, D’Angeli IM, De Waele J, Miller AZ, Carbone C, Baldantoni D (2019) Vermiculations from karst caves: the case of Pertosa-Auletta system (Italy). CATENA 182:104178

Alonso-Zarza A, Martín-Pérez A, Martín-García R (2012) Diagenesis of a drapery speleothem from Castañar Cave: from dissolution to dolomitization. Int J Speleol 41:251-266

Appiano A (1998) Manuale di immagine: intelligenza percettiva, creatività progetto. Meltemi Editore srl, Rome

Bajo P, Drysdale RN, Woodhead J, Hellstrom J, Hodell DA, Ferretti P, Voelker A, Zanchetta G, Rodrigues T, Wolff E, Tyler JJ, Frisia S, Spötl C, Fallick AE (2020) Persistent influence of obliquity on ice age terminations since the Middle Pleistocene transition. Science 367:1235-1239

Baker A, Hartmann A, Duan W, Hankin S, Comas-Bru L, Cuthbert MO, Treble PC, Banner J, Genty D, Baldini LM, Bartolome M, Moreno A, Perez-Mejias C, Werner M (2019) Global analysis reveals climatic controls on the oxygen isotope composition of cave drip water. Nat Commun 10(1):2984

Bartoli G, Gianni AM, Bonaiuto P (1996) Funzione della percezione visiva nell' ambito del museo. La nuova Italia, Florence

Barton HA, Northup DE (2007) Geomicrobiology in cave environments: past, current and future perspectives. J Cave Karst Stud 69(1):163-178

Benazzi S, Douka K, Fornai C, Bauer CC, Kullmer O, Svoboda J, Pap I, Mallegni F, Bayle P, Coquerelle M (2011) Early dispersal of modern humans in Europe and implications for Neanderthal behaviour. Nature 479(7374):525-529

Benazzi S, Slon V, Talamo S, Negrino F, Peresani M, Bailey SE, Sawyer S, Panetta D, Vicino G, Starnini E (2015) The makers of the Protoaurignacian and implications for Neandertal extinction. Science 348(6236):793-796

Bontognali TR, D’Angeli IM, Tisato N, Vasconcelos C, Bernasconi SM, Gonzales ER, De Waele J (2016) Mushroom speleothems: stromatolites that formed in the absence of phototrophs. Front Earth Sci 4:49

Boston PJ, Spilde MN, Northup DE, Melim LA, Soroka DS, Kleina LG, Lavoie KH, Hose LD, Mallory LM, Dahm CN, Crossey LJ, Schelble RT (2001) Cave biosignature suites: microbes, minerals, and Mars. Astrobiology 1(1):25-55 
Brilha J (2016) Inventory and quantitative assessment of geosites and geodiversity sites: a review. Geoheritage 8:119-134

Chiarini V, Couchoud I, Drysdale R, Bajo P, Milanolo S, Frisia S, Greig A, Hellstrom J, De Waele J (2017) Petrographical and geochemical changes in Bosnian stalagmites and their palaeoenvironmental significance. Int J Speleol 46(1):33-49

Columbu A, Chiarini V, De Waele J, Drysdale R, Woodhead J, Hellstrom J, Forti P (2017a) Late quaternary speleogenesis and landscape evolution in the northern Apennine evaporite areas. Earth Surf Proc Land 42(10):1447-1459

Columbu A, Drysdale R, Capron E, Woodhead J, De Waele J, Sanna L, Hellstrom J, Bajo P (2017b) Early last glacial intra-interstadial climate variability recorded in a Sardinian speleothem. Quatern Sci Rev 169:391-397

Columbu A, Drysdale R, Hellstrom J, Woodhead J, Cheng H, Hua Q, Zhao J-X, Montagna P, Pons-Branchu E, Edwards RL (2019a) $\mathrm{U}-\mathrm{Th}$ and radiocarbon dating of calcite speleothems from gypsum caves (Emilia Romagna, North Italy). Quat Geochronol 52:51-62

Columbu A, Spötl C, De Waele J, Yu T-L, Shen C-C, Gázquez F (2019b) A long record of MIS 7 and MIS 5 climate and environment from a western Mediterranean speleothem (SW Sardinia, Italy). Quatern Sci Rev 220:230-243

Columbu A, Chiarini V, Spötl C, Benazzi S, Hellstrom J, Cheng H, De Waele J (2020) Speleothem record attests to stable environmental conditions during Neanderthal-Modern Human turnover in Southern Italy. Nat Ecol Evol 4(9):1188-1195

Comas-Bru L, Rehfeld K, Roesch C, Amirnezhad-Mozhdehi S, Harrison SP, Atsawawaranunt K, Ahmad SM, Ait Brahim Y, Baker A, Bosomworth M, Breitenbach SFM, Burstyn Y, Columbu A, Deininger M, Demény A, Dixon B, Fohlmeister J, Hatvani IG, Hu J, Kaushal N, Kern Z, Labuhn I, Lechleitner FA, Lorrey A, Martrat B, Novello VF, Oster J, Pérez-Mejías C, Scholz, D, Scroxton N, Sinha N, Ward BM, Warken S, Zhang H, and the SISAL members (2020) SISALv2: a comprehensive speleothem isotope database with multiple age-depth models. Earth Syst Sci Data 12(4): 2579-2606

Coratza P, De Waele J (2012) Geomorphosites and natural hazards: teaching the importance of geomorphology in society. Geoheritage 4(3):195-203

Culver DC, Pipan T (2019) The biology of caves and other subterranean habitats. Oxford University Press, New York

Currens JC (1981) Kentucky caves: natures mineral museums. Rocks \& Minerals 56:93-97

de Lima JTM, de Souza CI (2020a) Research and educational geological collections in Brazil: the conflict between the field's paradigms of heritage's conservation and geology. Geoheritage 12(3):72

de Lima JTM, de Souza CI (2020b) Geological or cultural heritage? The ex situ scientific collections as a remnant of nature and culture. Geoheritage 12(1):3

Delle Rose M, Desideri D, Patianna M, Posi ME, Renzulli A, Zanchetta G (2014) Carbonate Accretion Processes, Conservation and Enjoyment of the 'Mannute Caves' Geoheritage Site (Salento, Southern Italy). Geoheritage 6:257-269

Dumitru OA, Austermann J, Polyak VJ, Fornos JJ, Asmerom Y, Ginés J, Ginés A, Onac BP (2019) Constraints on global mean sea level during Pliocene warmth. Nature 574(7777):233-236

Economou M (2004) Evaluation strategies in the cultural sector: the case of the Kelvingrove Museum and Art Gallery in Glasgow. Museum Soc 2:30-46

Fairchild IJ, Baker A (2012) Speleothem science: from process to past environments. Wiley, Chichester

Finlayson C, Carrion JS (2007) Rapid ecological turnover and its impact on Neanderthal and other human populations. Trends Ecol Evol 22(4):213-222
Forti P, Sanna L (2010) The Naica Project-a multidisciplinary study of the largest gypsum crystals of the world. Episodes 33(1):23-32

Frappier AB (2008) A stepwise screening system to select stormsensitive stalagmites: taking a targeted approach to speleothem sampling methodology. Quatern Int 187(1):25-39

Galli E, Brigatti MF, Malferrari D, Sauro F, De Waele J (2013) Rossiantonite, $\mathrm{Al}_{3}\left(\mathrm{PO}_{4}\right)\left(\mathrm{SO}_{4}\right)_{2}(\mathrm{OH})_{2}\left(\mathrm{H}_{2} \mathrm{O}\right)_{10} \cdot 4 \mathrm{H}_{2} \mathrm{O}$, a new hydrated aluminum phosphate-sulfate mineral from Chimanta massif, Venezuela: Description and crystal structure. Am Miner 98(10):1906-1913

Higham T, Douka K, Wood R, Ramsey CB, Brock F, Basell L, Camps M, Arrizabalaga A, Baena J, Barroso-Ruíz C (2014) The timing and spatiotemporal patterning of Neanderthal disappearance. Nature 512(7514):306-309

Hoffmann DL, Standish CD, Garcia-Diez M, Pettitt PB, Milton JA, Zilhao J, Alcolea-Gonzalez JJ, Cantalejo-Duarte P, Collado H, de Balbin R, Lorblanchet M, Ramos-Munoz J, Weniger GC, Pike AWG (2018) U-Th dating of carbonate crusts reveals Neandertal origin of Iberian cave art. Science 359(6378):912-915

Kotler N, Kotler P (1999) Museum strategy and marketing: designing mission building audiences generating revenue and resources. Jossey-Bass, San Francisco

Leuko S, Koskinen K, Sanna L, D’Angeli IM, De Waele J, Marcia P, Moissl-Eichinger C, Rettberg P (2017) The influence of human exploration on the microbial community structure and ammonia oxidizing potential of the Su Bentu limestone cave in Sardinia. Italy Plos One 12(7):e0180700

Lourenço MC, Wilson L (2013) Scientific heritage: Reflections on its nature and new approaches to preservation, study and access. Stud Hist Philos Sci Part A 44(4):744-753

Lucisano P, Piemontese ME (1988) GULPEASE: una formula per la predizione della difficoltà dei testi in lingua italiana. Scuola Città $3: 110-124$

MacDonald S (1992) Cultural imagining among museum visitors: a case study. Int J Museum Manage Curatorship 11(4):401-409

Marciani G, Ronchitelli A, Arrighi S, Badino F, Bortolini E, Boscato P, Boschin F, Crezzini J, Delpiano D, Falcucci A (2020) Lithic techno-complexes in Italy from 50 to 39 thousand years BP: an overview of lithic technological changes across the Middle-Upper Palaeolithic boundary. Quatern Int 551:123-149

McDermott F (2004) Palaeo-climate reconstruction from stable isotope variations in speleothems: a review. Quatern Sci Rev 23(7-8):901-918

Mecchia M, Sauro F, Piccini L, Columbu A, De Waele J (2019) A hybrid model to evaluate subsurface chemical weathering and fracture karstification in quartz sandstone. J Hydrol 572:745-760

Melchionna M, Di Febbraro M, Carotenuto F, Rook L, Mondanaro A, Castiglione S, Serio C, Vero VA, Tesone G, Piccolo M (2018) Fragmentation of Neanderthals' pre-extinction distribution by climate change. Palaeogeogr Palaeoclimatol Palaeoecol 496:146-154

Merzagora M, Rodari P (2007) La scienza in mostra: musei, science centre e comunicazione. Pearson Italia Spa, Genova

Miglietta AM, Pace R, Boero F (2011) I pannelli nei musei. Il punto di vista dei ragazzi. Museol Sci 5(1-2):136-141

Moseley GE, Spötl C, Brandstätter S, Erhardt T, Luetscher M, Edwards RL (2020) NALPS19: Sub-orbital scale climate variability recorded in Northern Alpine speleothems during the last glacial period. Clim Past 16(1):29-50

NGRIP, North Greenland Ice Core Project members (2004) High-resolution record of Northern Hemisphere climate extending into the last interglacial period. Nature 431(7005):147-151

Nyssen J, Yonas M, Annys S, Ghebreyohannes T, Smidt W, Welegerima K, Gebreselassie S, Sembroni A, Dramis F, Ek C, Causer D (2020) The Zeyi cave geosite in northern Ethiopia. Geoheritage 12:1-15

Panizza M (2001) Geomorphosites: concepts, methods and examples of geomorphological survey. Chin Sci Bull 46:4-5 
Parise M (2011) Some considerations on show cave management issues in Southern Italy. In: van Beynen P (ed) Karst management. Springer, Dordrecht, pp 159-167

Pereira P, Pereira D (2010) Methodological guidelines for geomorphosite assessment. Géomorphol Relief Processus Environ $16: 215-222$

Posi ME, Belmonte G, Boero F, Miglietta AM (2010) Una sala come piace a te. Front-end evaluation per la realizzazione di una nuova proposta espositiva. Museol Sci 4:152-159

Pozzi JP, Rousseau L, Falgueres C, Mahieux G, Deschamps P, Shao Q, Kachi D, Bahain JJ, Tozzi C (2019) U-Th dated speleothem recorded geomagnetic excursions in the Lower Brunhes. Sci Rep 9(1):1114

Railsback LB, Liang F, Vidal Romaní JR, Blanche Garrett K, Sellers RC, Vaqueiro-Rodríguez M, Grandal-d'Anglade A, Chen H, Edwards RL (2017) Radiometric, isotopic, and petrographic evidence of changing interglacials over the past 550,000 years from six stalagmites from the Serra do Courel in the Cordillera Cantábrica of northwestern Spain. Palaeogeogr Palaeoclimatol Palaeoecol 466:137-152

Regattieri E, Zanchetta G, Isola I, Zanella E, Drysdale RN, Hellstrom JC, Zerboni A, Dallai L, Tema E, Lanci L, Costa E, Magrì F (2019) Holocene Critical Zone dynamics in an Alpine catchment inferred from a speleothem multiproxy record: disentangling climate and human influences. Sci Rep 9(1):17829

Revilla-Martín N, Budinski I, Puig-Montserrat X, Flaquer C, LópezBaucells A (2020) Monitoring cave-dwelling bats using remote passive acoustic detectors: a new approach for cave monitoring. Bioacoustics 1-16

Reynard E, Panizza M (2005) Geomorphosites: definition, assessment and mapping. An introduction. Géomorphol Relief Processus Environ 11:177-180

Romandini M, Oxilia G, Bortolini E, Peyrégne S, Delpiano D, Nava A, Panetta D, Di Domenico G, Martini P, Arrighi S (2020) A late Neanderthal tooth from northeastern Italy. J Hum Evol 147:102867

Ruban DA (2018) Karst as important resource for geopark-based tourism: Current state and biases. Resources 7(4):82

Sano K, Arrighi S, Stani C, Aureli D, Boschin F, Fiore I, Spagnolo V, Ricci S, Crezzini J, Boscato P (2019) The earliest evidence for mechanically delivered projectile weapons in Europe. Nat Ecol Evol 3(10):1409-1414

Santangelo N, Romano P, Santo A (2015) Geo-itineraries in the Cilento Vallo di Diano Geopark: A tool for tourism development in Southern Italy. Geoheritage 7(4):319-335

Sardella R, Iurino DA, Mecozzi B, Sigari D, Bona F, Bellucci L, Coltorti M, Conti J, Lembo G, Mutillo B, Mazzini I (2019) Grotta Romanelli (Lecce, Southern Italy) between past and future: new studies and perspectives for an archaeo-geosite symbol of the Palaeolithic in Europe. Geoheritage 11:1413-1432

Sauro F, Cappelletti M, Ghezzi D, Columbu A, Hong PY, Zowawi HM, Carbone C, Piccini L, Vergara F, Zannoni D (2018) Microbial diversity and biosignatures of amorphous silica deposits in orthoquartzite caves. Sci Rep 8(1):17569

Sauro F, Mecchia M, Piccini L, De Waele J, Carbone C, Columbu A, Pisani L, Vergara F (2019) Genesis of giant sinkholes and caves in the quartz sandstone of Sarisariñama tepui, Venezuela. Geomorphology 342:223-238

Scroxton N, Gagan MK, Dunbar GB, Ayliffe LK, Hantoro WS, Shen CC, Hellstrom JC, Zhao JX, Cheng H, Edwards RL, Sun H, Rifai $\mathrm{H}$ (2016) Natural attrition and growth frequency variations of stalagmites in southwest Sulawesi over the past 530,000 years. Palaeogeogr Palaeoclimatol Palaeoecol 441:823-833

Sharples C (1995) Geoconservation in forest management - principles and procedures. Tasforests 7:37-50

Spötl C, Mattey D (2012) Scientific drilling of speleothems-a technical note. Int J Speleol 41(1):29-34

Stahlschmidt MC, Collin TC, Fernandes DM, Bar-Oz G, Belfer-Cohen A, Gao Z, Jakeli N, Matskevich Z, Meshveliani T, Pritchard JK, McDermott F, Pinhasi R (2019) Ancient Mammalian and Plant DNA from Late Quaternary Stalagmite Layers at Solkota Cave Georgia. Sci Rep 9(1):6628

Staubwasser M, Drăgușin V, Onac BP, Assonov S, Ersek V, Hoffmann DL, Veres D (2018) Impact of climate change on the transition of Neanderthals to modern humans in Europe. Proc Natl Acad Sci 115(37):9116-9121

Tisato N, Torriani SF, Monteux S, Sauro F, De Waele J, Tavagna ML, D'Angeli IM, Chailloux D, Renda M, Eglinton TI, Bontognali TR (2015) Microbial mediation of complex subterranean mineral structures. Sci Rep 5(1):1-10

Trontelj P, Borko Š, Delić T (2019) Testing the uniqueness of deep terrestrial life. Sci Rep 9(1):1-9

van Beynen PE (ed) (2011) Karst management. Springer Science \& Business Media, Dordrecht

Vanghi V, Frisia S, Borsato A (2017) Genesis and microstratigraphy of calcite coralloids analysed by high resolution imaging and petrography. Sed Geol 359:16-28

Walczak IW, Baldini JUL, Baldini LM, McDermott F, Marsden S, Standish CD, Richards DA, Andreo B, Slater J (2015) Reconstructing high-resolution climate using CT scanning of unsectioned stalagmites: a case study identifying the mid-Holocene onset of the Mediterranean climate in southern Iberia. Quatern Sci Rev 127:117-128

Weij R, Woodhead J, Hellstrom J, Sniderman K, Reed L, Drysdale R, Bajo P (2018) Speleothem rubble as a new low-impact tool for cave-based palaeoclimate studies. In\&nbsp;EGU General Assembly Conference Abstracts, 13848

Williams P (2008) World heritage caves and karst. IUCN, Gland

Wimbledon WAP (1996) GEOSITES-a new conservation initiative. Episodes J Int Geosci 19:87-88

Wolf D, Kolb T, Alcaraz-Castano M, Heinrich S, Baumgart P, Calvo R, Sanchez J, Ryborz K, Schafer I, Bliedtner M, Zech R, Zoller L, Faust D (2018) Climate deteriorations and Neanderthal demise in interior Iberia. Sci Rep 8(1):7048

Woodhead JD, Sniderman JK, Hellstrom J, Drysdale RN, Maas R, White N, White S, Devine P (2019) The antiquity of Nullarbor speleothems and implications for karst palaeoclimate archives. Sci Rep 9(1):1-8

Wray RA, Sauro F (2017) An updated global review of solutional weathering processes and forms in quartz sandstones and quartzites. Earth Sci Rev 171:520-557 